\title{
FAKTOR YANG BERHUBUNGAN DENGAN KEJADIAN PENYAKIT GINJAL KRONIK PADA PENDERITA HIPERTENSI DI INDONESIA
}

\author{
Factors Associated with Chronic Kidney Disease Incidence among Patients \\ with Hypertension in Indonesia
}

\author{
Saniya Ilma Arifa, Mahalul Azam, Oktia Woro Kasmini Handayani \\ Ilmu Kesehatan Masyarakat, Fakultas Ilmu Keolahragaan, Universitas Negeri Semarang \\ (saniyailmaa@gmail.com)
}

\begin{abstract}
ABSTRAK
Penyakit Ginjal Kronik (PGK) berkontribusi pada beban penyakit dunia karena prevalensinya terus meningkat dan menempati beban biaya kesehatan paling tinggi kedua di Indonesia setelah penyakit jantung. Hipertensi merupakan salah satu faktor dominan yang menyebabkan penyakit ginjal kronik. Penelitian ini bertujuan mengetahui prevalensi dan faktor-faktor yang berhubungan dengan kejadian PGK pada penderita hipertensi di Indonesia. Jenis penelitian ini adalah penelitian analitik observasional dengan pendekatan cross sectional. Data bersumber dari data sekunder hasil riskesdas tahun 2013. Data dianalisis menggunakan chi square dan regresi logistik. Didapatkan prevalensi PGK pada penderita hipertensi di Indonesia sebesar 0,5\%. Terdapat hubungan yang signifikan antara variabel usia kategori 45-54 tahun ( $\mathrm{OR}=4,7 ; \mathrm{p}<0,05 ; 95 \% \mathrm{CI}=1,103-20,125)$, usia kategori 55-64 tahun $(\mathrm{OR}=4,7 ; \mathrm{p}<0,05 ; 95 \% \mathrm{CI}=1,094-20,434)$, jenis kelamin $(\mathrm{OR}=1,78 ; \mathrm{p}<0,05 ; 95 \% \mathrm{CI}=1,072-2,967)$, riwayat $\mathrm{DM}(\mathrm{OR}=4 ; \mathrm{p}<0,05 ; 95 \% \mathrm{CI}=1,926-8,444)$, dan riwayat batu ginjal $(\mathrm{OR}=132,2 ; \mathrm{p}<0,05 ; 95 \% \mathrm{CI}=79,5-$ $219,9)$ dengan kejadian PGK pada penderita hipertensi di Indonesia. Riwayat DM, riwayat batu ginjal dan kadar kolesterol total merupakan variabel dominan kejadian PGK pada penderita hipertensi di Indonesia.
\end{abstract}

Kata kunci : Penyakit ginjal kronik, hipertensi, prevalensi

\section{ABSTRACT}

Chronic kidney disease (CKD) contributes to the burden of world disease as its prevalence continues to rise and occupies the second highest cost of health burden in Indonesia after heart disease. Hypertension is one of the dominant factors that cause chronic kidney disease. This study aimed to determine the prevalence and factors related to CKD in hypertension patients in Indonesia. This is an observational analytic research with cross sectional approach. Data sourced from secondary data result of riskesdas year 2013. Data were analyzed using chi-square and logistic regression. The prevalence of PGK in hypertension patients in Indonesia is 0,5\%. There is a significant association between the variables of age category of $45-54$ years $(O R=4,7 ; p<0,05)$, the age category of 55-64 years (OR=4,7; $p<0,05)$, sex $(O R=1,78 ; p<0,05)$, DM history $(O R=4, p<0,05)$ and kidney stones history $(O R=132,2 ; p<0,05)$ and the incidence of CKD in hypertension patients in Indonesia. DM history, kidney stones history and total cholesterol levels is the dominant variable incidence of PGK in hypertensive patients in Indonesia. Keywords: Chronic kidney disease, hypertension, prevalence 


\section{PENDAHULUAN}

Penyakit Ginjal Kronik (PGK) didefinisikan sebagai kerusakan ginjal atau Glomerulus Filtrate Rate $<60 \mathrm{ml} /$ minute $/ 1,73$ selama 3 bulan atau lebih dan dikatakan sudah mencapai tahap akhir jika GFR mencapai $<15 \mathrm{ml} /$ minute/1,73 dengan atau tidak dialisis. ${ }^{1}$ Menurut World Health Organization (WHO), penyakit ginjal kronis berkontribusi pada beban penyakit dunia dengan angka kematian sebesar 850.000 jiwa per tahun. ${ }^{2}$ Melansir data dari 7th Annual Report of Indonesian Renal Registry, jumlah kematian pasien hemodialisis tahun 2014 di Indonesia sebesar 2.221 jiwa dengan penyakit kardiovaskuler sebagai penyebab kematian tertinggi $(59 \%){ }^{3}$

PGK juga menempati beban biaya kesehatan paling tinggi kedua di Indonesia setelah penyakit jantung. Pada tahun 2000 terdapat sebanyak 2.617 pasien yang menjalani hemodialisis dengan beban biaya yang ditanggung oleh Askes sebesar Rp. 32,4 milyar dan pada tahun 2004 menjadi 6.314 kasus dengan biaya Rp. 67,2 milyar. ${ }^{4}$ Berdasarkan data BPJS Kesehatan pada tahun 2014 terdapat 1,4 juta kasus gagal ginjal dengan biaya Rp. 2,2 triliun. Sampai triwulan ketiga 2015, tercatat 1,2 juta kasus gagal ginjal yang dibiayai BPJS yang nilainya mencapai Rp. 1,6 triliun. $^{5}$

Prevalensi PGK secara global telah meningkat setiap tahunnya. The United States Renal Data System (USRDS) mencatat bahwa jumlah pasien yang dirawat karena End Stage Renal Disease (ESRD) secara global diperkirakan 3.010 .000 pada tahun 2012 dengan tingkat pertumbuhan 7\% dan meningkat 3.200.000 pada tahun 2013 dengan tingkat pertumbuhan $6 \% .{ }^{6,7}$ Berdasarkan data yang dihimpun dari 5th Annual Report of Indonesian Renal Registry, jumlah penderita PGK di Indonesia pada tahun 2011 tercatat sebesar 22.304 dengan $68,8 \%$ kasus baru dan pada tahun 2012 meningkat menjadi 28.782 dengan $68,1 \%$ kasus baru. ${ }^{8}$

Laporan Riset Kesehatan Dasar (Riskesdas) tahun 2013 menunjukkan bahwa prevalensi PGK di Indonesia sekitar 0,2\%, meningkat seiring dengan bertambahnya umur. Meningkat tajam pada kelompok umur 35-44 tahun $(0,3 \%)$, diikuti umur 45-54 tahun (0,4\%), dan umur 55-74 tahun $(0,5 \%)$, tertinggi pada kelompok umur $\geq 75$ tahun $(0,6 \%)$. Selain itu, diketahui prevalensi pada jenis kelamin laki-laki $(0,3 \%)$ lebih tinggi dari perem- puan $(0,2 \%){ }^{9}$

Hipertensi merupakan faktor dominan penyebab penyakit ginjal kronik. ${ }^{10,11}$ Hasil studi kohort dari Ghana menyatakan dari 365 pasien rawat jalan dengan hipertensi, 110 pasien $(30,2 \%)$ memiliki serum kreatinin $>140$ umol/L $(1,6 \mathrm{mg} /$ dL), 48 pasien memiliki serum kreatinin $>400$ umol/L $(>4,5 \mathrm{mg} / \mathrm{dL})$, dan $96(25,5 \%)$ memiliki proteinuria. ${ }^{12}$ Studi kohort lain dari Burkina Faso, 117 dari 317 (44\%) pasien dengan hipertensi yang dirawat di rumah sakit menderita PGK. ${ }^{13}$ PGK pada penderita hipertensi dipengaruhi oleh faktor ras, usia, jenis kelamin, tingkat pendidikan, status perkawinan, status pekerjaan, status tempat tinggal, status ekonomi, perilaku merokok, kurang aktivitas fisik, pola konsumsi air putih, konsumsi minuman beralkohol, konsumsi minuman bersoda, konsumsi minuman berenergi, penggunaan obat analgetika NSAID, riwayat penyakit diabetes mellitus, riwayat penyakit glomerulonefritis, riwayat penyakit batu ginjal, riwayat penyakit infeksi saluran kemih, riwayat penyakit batu saluran kemih, riwayat keluarga, riwayat BBLR, status obesitas, kadar kolesterol total, kadar HDL, kadar LDL, kadar trigliserida, dan fasilitas pengobatan yang tidak tersedia atau tidak terjangkau. ${ }^{14-27}$ Pada sisi lain, Riskesdas 2013 telah melakukan survei dan menyediakan data usia, jenis kelamin, pendidikan, status perkawinan, status tempat tinggal, status pekerjaan, status ekonomi, riwayat penyakit diabetes mellitus, riwayat penyakit batu ginjal, status obesitas, kadar kolesterol total, kadar LDL, kadar HDL, dan kadar trigliserida.

Di Indonesia, sejauh pengetahuan peneliti belum diketahui prevalensi kejadian penyakit ginjal kronik pada penderita hipertensi di Indonesia serta faktor risikonya menurut data Riskesdas 2013 belum pernah dianalisis. Berkaitan dengan hal tersebut, penelitian ini dilakukan untuk mengetahui prevalensi kejadian penyakit ginjal kronik pada penderita hipertensi di Indonesia, dan membuktikan faktor-faktor apa saja yang berhubungan dengan kejadian penyakit ginjal kronik pada penderita hipertensi di Indonesia.

\section{BAHAN DAN METODE}

Jenis penelitian yang digunakan adalah analitik observasional dengan desain cross sectional, menggunakan data sekunder hasil Riskesdas tahun 
2013. Variabel yang dianalisis meliputi usia, jenis kelamin, tingkat pendidikan, status perkawinan, status pekerjaan, status ekonomi, riwayat penyakit diabetes mellitus, riwayat penyakit batu ginjal, status obesitas, kadar kolesterol total, kadar LDL, kadar HDL, dan kadar trigliserida. Penelitian ini dilaksanakan pada tahun 2017 dan mencakup seluruh wilayah Indonesia. Populasi penelitian ini adalah seluruh individu yang menderita hipertensi menurut hasil Riskesdas tahun 2013 yang diukur lengkap berdasarkan biomedis (secara nasional) di Indonesia. Sampel penelitian yaitu individu yang memenuhi kriteria eksklusi. Data responden akan dieksklusi jika terdapat data yang tidak lengkap pada variabel-variabel yang diteliti (missing data).

Analisis data yang dilakukan dalam penelitian ini antara lain analisis univariat untuk mendeskripsikan karakteristik setiap variabel penelitian, analisis bivariat dengan chi-square untuk mengetahui hubungan antara variabel bebas dengan variabel terikat dengan keeratan hubungan dinilai pada tingkat kepercayaan $95 \%$, dan dilanjutkan dengan analisis multivariat menggunakan regresi logistik untuk mengetahui variabel yang paling berpengaruh terhadap variabel terikat.

\section{HASIL}

Terdapat 11.405 sampel yang memenuhi kriteria inklusi. Subjek terbanyak adalah yang berusia 45-54 tahun $(36,7 \%)$, perempuan lebih banyak dari pada laki-laki (63,3\%), tingkat pendidikan subjek terbanyak pada kategori tamat SD/MI (36,9\%), status perkawinan terbanyak yaitu menikah $(80,4 \%)$, status pekerjaan terbanyak yaitu bekerja (57,3\%), status ekonomi subjek terbanyak pada kategori kuintil 3 (23,3\%). Sampel yang memiliki riwayat diabetes mellitus sebanyak $96,3 \%$, riwayat batu ginjal sebanyak $98,6 \%$, status obesitas sebanyak $40,1 \%$, kadar kolesterol total berisiko sebanyak $56 \%$, kadar HDL berisiko sebanyak $80,4 \%$, kadar LDL berisiko sebanyak $83,6 \%$, dan kadar trigliserida berisiko sebanyak $31,2 \%$.

Dari 11.405 sampel penderita hipertensi di Indonesia, sebanyak 63 sampel $(0,5 \%)$ menderita PGK. Dari analisis bivariat dapat diketahui faktor risiko yang berhubungan dengan kejadian PGK antara adalah usia kategori 45-54 tahun $(\mathrm{OR}=4,7$; $\mathrm{p}<0,05)$, usia kategori 55-64 tahun $(\mathrm{OR}=4,7$;
Tabel 1. Karakteristik Subjek Penelitian

\begin{tabular}{|c|c|c|}
\hline Variabel & $\mathbf{n}$ & $\%$ \\
\hline \multicolumn{3}{|l|}{ Usia (tahun) } \\
\hline $75+$ & 553 & 4,8 \\
\hline $65-74$ & 1439 & 12,6 \\
\hline $55-64$ & 2544 & 22,3 \\
\hline $45-54$ & 3004 & 26,3 \\
\hline $35-44$ & 2450 & 21,5 \\
\hline $15-34$ & 1415 & 12,4 \\
\hline \multicolumn{3}{|l|}{ Jenis Kelamin } \\
\hline Laki-laki & 4187 & 36,7 \\
\hline Perempuan & 7218 & 63,3 \\
\hline \multicolumn{3}{|l|}{ Tingkat Pendidikan } \\
\hline Tidak/belum pernah sekolah & 1289 & 11,3 \\
\hline Tidak tamat SD/MI & 2048 & 18,0 \\
\hline Tamat SD/MI & 4213 & 36,9 \\
\hline Tamat SLTP/MTS & 1484 & 13,0 \\
\hline Tamat SLTA/MA & 1847 & 16,2 \\
\hline Tamat D1-D3/S1 & 524 & 4,6 \\
\hline \multicolumn{3}{|l|}{ Status Perkawinan } \\
\hline Menikah & 9171 & 80,4 \\
\hline Lainnya & 2234 & 19,6 \\
\hline \multicolumn{3}{|l|}{ Status Pekerjaan } \\
\hline Bekerja & 6532 & 57,3 \\
\hline Tidak Bekerja & 4873 & 42,7 \\
\hline \multicolumn{3}{|l|}{ Status Ekonomi } \\
\hline Kuintil 1 & 1782 & 15,6 \\
\hline Kuintil 2 & 2434 & 21,3 \\
\hline Kuintil 3 & 2661 & 23,3 \\
\hline Kuintil 4 & 2588 & 22,7 \\
\hline Kuintil 5 & 1940 & 17,0 \\
\hline \multicolumn{3}{|l|}{ Riwayat DM } \\
\hline Ya & 427 & 3,7 \\
\hline Tidak & 10978 & 96,3 \\
\hline \multicolumn{3}{|l|}{ Riwayat Batu Ginjal } \\
\hline Ya & 154 & 1,4 \\
\hline Tidak & 11251 & 98,6 \\
\hline \multicolumn{3}{|l|}{ Status Obesitas } \\
\hline Obesitas & 4579 & 40,1 \\
\hline Tidak Obesitas & 6826 & 59,9 \\
\hline \multicolumn{3}{|l|}{ Kadar Kolesterol Total } \\
\hline Berisiko & 6392 & 56,0 \\
\hline Tidak Berisiko & 5013 & 44,0 \\
\hline \multicolumn{3}{|l|}{ Kadar HDL } \\
\hline Berisiko & 9171 & 80,4 \\
\hline Tidak Berisiko & 2234 & 19,6 \\
\hline \multicolumn{3}{|l|}{ Kadar LDL } \\
\hline Berisiko & 9538 & 83,6 \\
\hline Tidak Berisiko & 1867 & 16,4 \\
\hline \multicolumn{3}{|l|}{ Kadar Trigliserida } \\
\hline Berisiko & 3562 & 31,2 \\
\hline Tidak Berisiko & 7843 & 68,8 \\
\hline
\end{tabular}

Sumber : Kemenkes RI, 2013 
Tabel 2. Hubungan Berbagai Faktor Risiko dengan Kejadian Penyakit Ginjal Kronik pada Penderita Hipertensi di Indonesia

\begin{tabular}{|c|c|c|c|c|c|c|c|}
\hline \multirow{3}{*}{ Variabel } & \multicolumn{3}{|c|}{ PGK } & \multirow{3}{*}{$\mathbf{p}$} & \multirow{3}{*}{$\mathbf{R P}$} & \multicolumn{2}{|c|}{$95 \%$ CI } \\
\hline & Ya & Tidak & Total & & & \multirow{2}{*}{ Lower } & \multirow{2}{*}{ Upper } \\
\hline & $n(\%)$ & $n(\%)$ & $\mathbf{n}$ & & & & \\
\hline \multicolumn{8}{|l|}{ Usia (tahun) } \\
\hline $75+$ & $3(0,5)$ & $550(99,5)$ & 553 & 0,139 & 3,838 & 0,643 & 22,908 \\
\hline $65-74$ & $8(0,6)$ & $1431(99,4)$ & 1439 & 0,109 & 3,933 & 0,837 & 18,490 \\
\hline $55-64$ & $17(0,7)$ & $2527(99,3)$ & 2544 & 0,039 & 4,728 & 1,094 & 20,434 \\
\hline $45-54$ & $20(0,7)$ & $2984(99,3)$ & 3004 & 0,037 & 4,710 & 1,103 & 20,125 \\
\hline $35-44$ & $9(0,4)$ & $2441(99,6)$ & 2450 & 0,347 & 2,599 & 0,562 & 12,012 \\
\hline $15-34$ & $2(0,1)$ & $1413(99,9)$ & 1415 & Reference & 1 & & \\
\hline \multicolumn{8}{|l|}{ Jenis Kelamin } \\
\hline Laki-laki & $30(0,7)$ & $4157(99,3)$ & 4187 & 0,034 & 1,783 & 1,072 & 2,967 \\
\hline Perempuan & $29(0,4)$ & $7189(99,6)$ & 7218 & & & & \\
\hline \multicolumn{8}{|l|}{ Tingkat Pendidikan } \\
\hline Tidak/belum pernah sekolah & $9(0,7)$ & $1280(99,3)$ & 1289 & 0,739 & 1,829 & 0,397 & 8,438 \\
\hline Tidak tamat SD/MI & $8(0,4)$ & $2040(99,6)$ & 2048 & 1,000 & 1,023 & 0,218 & 4,805 \\
\hline Tamat SD/MI & $27(0,6)$ & $4186(99,4)$ & 4213 & 0,765 & 1,679 & 0,400 & 7,041 \\
\hline Tamat SLTP/MTS & $5(0,3)$ & $1479(99,7)$ & 1484 & 1,000 & 0,883 & 0,172 & 4,536 \\
\hline Tamat SLTA/MA & $8(0,4)$ & $1839(99,6)$ & 1847 & 1,000 & 1,135 & 0,242 & 5,328 \\
\hline Tamat D1-D3/S1 & $2(0,4)$ & $522(99,6)$ & 524 & Reference & 1 & & \\
\hline \multicolumn{8}{|l|}{ Status Perkawinan } \\
\hline Menikah & $50(0,5)$ & $9121(99,5)$ & 9171 & 0,499 & 1,353 & 0,667 & 2,748 \\
\hline Lainnya & $9(0,4)$ & $2225(99,6)$ & 2234 & & & & \\
\hline \multicolumn{8}{|l|}{ Status Pekerjaan } \\
\hline Bekerja & $39(0,6)$ & $6493(99,4)$ & 6532 & 0,214 & 1,455 & 0,850 & 2,491 \\
\hline Tidak Bekerja & $20(0,4)$ & $4853(99,6)$ & 4873 & 1,000 & & & \\
\hline \multicolumn{8}{|l|}{ Status Ekonomi } \\
\hline Kuintil 1 & $8(0,4)$ & $1774(99,6)$ & 1782 & 0,839 & 1,089 & 0,409 & 2,895 \\
\hline Kuintil 2 & $8(0,3)$ & $1932(99,7)$ & 1940 & 0,502 & 0,797 & 0,300 & 2,120 \\
\hline Kuintil 3 & $16(0,6)$ & $2645(99,4)$ & 2661 & 0,231 & 1,458 & 0,625 & 3,400 \\
\hline Kuintil 4 & $19(0,7)$ & $2569(99,3)$ & 2588 & Reference & 1,780 & 0,781 & 4,058 \\
\hline Kuintil 5 & $8(0,4)$ & $1932(99,6)$ & 1940 & & 1 & & \\
\hline \multicolumn{8}{|l|}{ Riwayat DM } \\
\hline $\mathrm{Ya}$ & $8(1,9)$ & $419(98,1)$ & 427 & 0,002 & 4,033 & 1,926 & 8,444 \\
\hline Tidak & $51(0,5)$ & $10927(99,5)$ & 10978 & & & & \\
\hline \multicolumn{8}{|l|}{ Riwayat Batu Ginjal } \\
\hline $\mathrm{Ya}$ & $38(24,7)$ & $116(75,3)$ & 154 & 0,000 & 132,2 & 79,5 & 219,9 \\
\hline Tidak & $21(0,2)$ & $11230(99,8)$ & 11251 & & & & \\
\hline \multicolumn{8}{|l|}{ Status Obesitas } \\
\hline Obesitas & $27(0,6)$ & $4552(99,4)$ & 4579 & 0,454 & 1,258 & 0,755 & 2,096 \\
\hline Tidak Obesitas & $32(0,5)$ & $6794(99,5)$ & 6826 & & & & \\
\hline \multicolumn{8}{|l|}{ Kadar Kolesterol Total } \\
\hline Berisiko & $28(0,4)$ & $6364(99,6)$ & 6392 & 0,230 & 0,708 & 0,426 & 1,179 \\
\hline Tidak Berisiko & $31(0,6)$ & $4982(99,4)$ & 5013 & & & & \\
\hline \multicolumn{8}{|l|}{ Kadar HDL } \\
\hline Berisiko & $43(0,5)$ & $9128(99,5)$ & 9171 & 0,195 & 0,655 & 0,369 & 1,160 \\
\hline Tidak Berisiko & $16(0,7)$ & $2218(99,3)$ & 2234 & & & & \\
\hline \multicolumn{8}{|l|}{ Kadar LDL } \\
\hline Berisiko & $52(0,5)$ & $9486(99,5)$ & 9538 & 0,446 & 1,454 & 0,662 & 3,196 \\
\hline Tidak Berisiko & $7(0,4)$ & $1860(99,6)$ & 1867 & & & & \\
\hline Kadar Trigliserida & & & & & & & \\
\hline Berisiko & $19(0,5)$ & $3543(99,5)$ & 3562 & 0,984 & 1,4 & 0,6 & 1,8 \\
\hline Tidak Berisiko & $40(0,5)$ & $7803(99,5)$ & 7843 & & & & \\
\hline
\end{tabular}


Tabel 3. Hasil Analisis Multivariat antara Berbagai Faktor Risiko dengan Kejadian Penyakit Ginjal Kronik pada Penderita Hipertensi di Indonesia

\begin{tabular}{lcccccccc}
\hline \multicolumn{1}{c}{ Variabel } & \multirow{2}{*}{ B } & \multirow{2}{*}{ S.E } & \multirow{2}{*}{ Wald } & \multirow{2}{*}{ df } & \multirow{2}{*}{ Sig. } & \multirow{2}{*}{$\operatorname{Exp(B)}$} & \multicolumn{2}{c}{ 95\% C.I. for EXP(B) } \\
\cline { 8 - 10 } & & & & & & Lower & Upper \\
\hline Riwayat DM &, 919 &, 463 & 3,933 & 1 &, 047 & 2,50 & 1,011 & 6,211 \\
Riwayat Batu Ginjal & 5,162 &, 293 & 310,9 & 1 &, 000 & 174,5 & 98,307 & 309,689 \\
Kadar Kolesterol Total &,- 631 &, 292 & 4,681 & 1 &, 031 &, 532 &, 300 &, 942 \\
Konstanta & $-6,025$ &, 250 & 582,2 & 1 &, 000 &, 002 & & \\
\hline
\end{tabular}

Sumber : Kemenkes RI, 2013

$\mathrm{p}<0,05)$, jenis kelamin $(\mathrm{OR}=1,78 ; \mathrm{p}<0,05)$, riwayat $\mathrm{DM}(\mathrm{OR}=4 ; \mathrm{p}<0,05)$, dan riwayat batu ginjal $(\mathrm{OR}=132,2 ; \mathrm{p}<0,05)$. Hasil analisis multivariat menunjukkan riwayat $\mathrm{DM}(\mathrm{p}=0,047)$, riwayat batu ginjal $(\mathrm{p}=0,000)$, dan kadar kolesterol total $(0,031)$ sebagai variabel dominan kejadian PGK pada penderita hipertensi di Indonesia.

\section{PEMBAHASAN}

Hasil uji statistik menunjukkan terdapat hubungan yang bermakna antara usia (kategori 4554 tahun dan 55-64 tahun) dengan kejadian PGK pada penderita hipertensi di Indonesia. Penelitian ini sejalan dengan penelitian Kang yang membuktikan adanya hubungan yang bermakna antara usia dengan kejadian penyakit ginjal kronik di Korea. ${ }^{28}$ Kelompok usia 77-79 tahun $(\mathrm{OR}=1,571 ; 95 \% \mathrm{CI}=$ $1,387-1,780 ; \mathrm{p}<0,001)$ dan $\geq 80$ tahun $(\mathrm{OR}=4,774$; $95 \% \mathrm{CI}=3,980-5,727 ; \mathrm{p}<0,001)$ lebih berisiko terkena penyakit ginjal kronik dibandingkan responden dengan kelompok usia 65-69 tahun. Gonzales, et al. juga membuktikan bahwa terdapat hubungan antara usia dengan penurunan nilai eGFR pada penderita hipertensi di Spanyol. ${ }^{11}$ Pertambah usia akan memengaruhi anatomi, fisiologi dan sitologi pada ginjal..$^{22,29}$ Setelah usia 30 tahun, ginjal akan mengalami atrofi dan ketebalan kortek ginjal akan berkurang sekitar $20 \%$ setiap dekade. Perubahan lain yang akan terjadi seiring dengan bertambahnya usia berupa penebalan membran basal glomerulus, ekspansi mesangium glomerular dan terjadinya deposit protein matriks ekstraselular sehingga menyebabkan glomerulosklerosis. .2,30 $^{2,3}$

Secara statistik terdapat hubungan yang bermakna antara jenis kelamin dengan kejadian PGK pada penderita hipertensi. Responden yang berjenis kelamin laki-laki berisiko 1,783 kali lebih besar terkena PGK dibandingkan dengan responden yang berjenis kelamin perempuan. Hal ini sama dengan penelitian yang dilakukan Pranandari \& Woro yang menyatakan bahwa jenis kelamin secara statistik memiliki hubungan yang bermakna dengan kejadian penyakit ginjal kronik pada pasien hemodialisis $(\mathrm{OR}=2,033 ; \mathrm{p}<0,05 ; 95 \% \mathrm{Cl}=1,028$ 4,023). ${ }^{15}$ Gonzales, et al. juga membuktikan bahwa terdapat hubungan antara jenis kelamin dengan penurunan nilai eGFR pada penderita hipertensi di Spanyol. ${ }^{11}$ Secara klinik laki-laki mempunyai risiko mengalami penyakit ginjal kronik 2 kali lebih besar dari pada perempuan. Hal ini dimungkinkan karena perempuan lebih memperhatikan kesehatan dan menjaga pola hidup sehat dibandingkan laki-laki, sehingga laki-laki lebih mudah terkena penyakit ginjal kronik dibandingkan perempuan. Perempuan lebih patuh dibandingkan laki-laki dalam menggunakan obat karena perempuan lebih dapat menjaga diri mereka sendiri serta bisa mengatur tentang pemakaian obat. ${ }^{15}$

Uji statistik membuktikan tidak ada hubungan yang bermakna antara tingkat pendidikan dengan kejadian PGK pada penderita hipertensi di Indonesia. Hal ini sejalan dengan hasil penelitian Sulistiowati \& Sri yang membuktikan bahwa tidak terdapat hubungan yang bermakna antara tingkat pendidikan dengan kejadian PGK $(\mathrm{p}=0,63) .{ }^{24}$ Semakin tinggi pendidikan seseorang maka akan semakin cepat memahami tentang kondisi penyakit yang dialami. Kurangnya pengetahuan dan kesadaran masyarakat untuk deteksi dini dalam memeriksakan dirinya ke pusat pelayanan kesehatan menjadi penyebab meningkatnya pasien penyakit ginjal kronik dikarenakan pada stadium awal tidak merasakan keluhan spesifik. Kebanyakan pasien datang dengan keluhan yang sudah berat dan pada saat dilakukan pemeriksaan lanjutan sudah berada pada stadium terminal (stadium 5). Hal ini diperkuat dengan teori yang menyatakan bahwa pada kasus PGK stadium 1 dan 2 belum memper- 
lihatkan gejala dan keluhan yang spesifik. ${ }^{16}$

Proporsi responden berstatus menikah yang mengalami PGK lebih banyak $(84,7 \%)$ dibandingkan responden yang berstatus lainnya. Secara statistik tidak terdapat hubungan antara status perkawinan dengan kejadian PGK pada penderita hipertensi. Penelitian Hartini juga menyatakan bahwa proporsi status pernikahan tertinggi pada kategori sudah menikah $(91,8 \%) .{ }^{16}$ Pernikahan adalah ikatan yang sah antara seorang pria dan wanita yang menimbulkan hak dan kewajiban antara mereka maupun keturunannya. Tingkat kemapanan dan kesibukan yang tinggi sangat erat kaitannya dengan tanggung jawab dalam keluarga. Hal ini membuat gaya hidup yang tidak sehat termasuk dalam cara memilih makanan dan beraktivitas yang bisa mempercepat terjadinya berbagai macam penyakit, salah satunya adalah PGK yang sebagian besar disebabkan oleh penyakit diabetes mellitus dan hipertensi yang merupakan penyebab PGK. ${ }^{16}$

PGK lebih banyak terjadi pada responden dengan status bekerja $(66,1 \%)$. Secara statistik tidak ada hubungan yang bermakna antara status pekerjaan dengan kejadian PGK pada penderita hipertensi. Penelitian ini sejalan dengan hasil penelitian Sulistiowati \& Sri yang membuktikan bahwa tidak terdapat hubungan yang bermakna antara pekerjaan dengan terjadinya penyakit ginjal kronik $(p=0,42) .{ }^{24}$ Berbagai jenis pekerjaan akan berpengaruh pada frekuensi dan distribusi penyakit. Tanpa disadari bahwa pekerjaan dapat menyebabkan gagal ginjal seperti pekerja kantoran yang duduk terus menerus sehingga menyebabkan terhimpitnya saluran ureter pada ginjal. Disamping itu, intensitas aktivitas sehari-hari seperti orang yang bekerja di panasan dan pekerja berat yang banyak mengeluarkan keringat lebih mudah terserang dehidrasi. Akibat dehidrasi, urin menjadi lebih pekat sehingga bisa menyebabkan terjadinya PGK. ${ }^{16}$

PGK lebih banyak terjadi pada responden dengan kuintil indeks kepemilikan ke 4 (32,2\%). Secara statistik tidak ada hubungan yang bermakna antara status ekonomi dengan kejadian PGK pada penderita hipertensi. Penelitian ini bertolak belakang dengan penelitian Sulistiowati \& Sri yang menyatakan terdapat hubungan antara status ekonomi dengan nilai eLFG $(p=0,01) .{ }^{24}$ Responden dengan sosial ekonomi rendah memiliki risiko lebih besar. Studi kohort di Amerika Serikat juga menyimpulkan bahwa laki-laki kulit putih dan perempuan Afrika-Amerika dengan status sosial ekonomi rendah memiliki risiko lebih besar untuk mengalami PGK dibandingkan dengan status sosial ekonomi yang lebih tinggi. Hal ini dimungkinkan karena akses untuk mendapatkan pemeriksaan fungsi ginjal dan pengobatan lebih kecil pada masyarakat dengan sosial ekonomi rendah. ${ }^{15,31}$

Hasil analisis menunjukkan bahwa responden dengan DM berisiko 4,03 kali lebih besar menderita PGK dibandingkan yang tidak DM. Hasil ini sejalan dengan penelitian Gonzales, et al. yang membuktikan bahwa terdapat hubungan antara diabetes mellitus dengan penurunan nilai eGFR pada penderita hipertensi di Spanyol. ${ }^{11} \mathrm{Pe}$ nelitian Hengkesa \& Ivy juga membuktikan adanya hubungan antara diabetes mellitus dengan penyakit ginjal kronik $(\mathrm{p}=0,00 ; \mathrm{OR}=5,134) .{ }^{23}$ Kadar gula dalam darah yang tinggi akan mempengaruhi struktur ginjal, merusak pembuluh darah halus di ginjal (glomerulosklerosis noduler dan difus). Kerusakan pembuluh darah menimbulkan kerusakan glomerulus yang berfungsi sebagai penyaring darah. Dalam keadaan normal protein tidak melewati glomerulus karena ukuran protein yang besar tidak dapat melewati lubang-lubang glomerulus yang kecil. Namun, karena kerusakan glomerulus, protein (albumin) dapat melewati glomerulus sehingga dapat ditemukan dalam urin yang disebut dengan mikroalbuminuria. Kondisi ini disebut juga sebagai penyakit ginjal diabetes. ${ }^{24,32,33} \mathrm{Hal}$ ini didukung pula dengan hasil Framingham Offspring Study pada 2.585 orang tanpa PGK, responden dengan DM berisiko 2,6 kali lebih besar untuk terjadinya PGK $(\mathrm{OR}=2,60$; 95\% CI:1,44-4,70) dalam 12 tahun. ${ }^{24,34}$

Hasil analisis juga menunjukkan bahwa terdapat hubungan antara riwayat batu ginjal dengan kejadian PGK pada penderita hipertensi di Indonesia. Responden dengan riwayat batu ginjal berisiko 132,2 kali lebih besar untuk terjadinya PGK dibandingkan yang tidak memiliki riwayat batu ginjal. Penelitian ini sejalan dengan hasil penelitian W. Shang, et al. yang membuktikan bahwa terdapat hubungan antara riwayat penyakit batu ginjal dengan kejadian penyakit ginjal kronik $(R R=1,47$; 95\% CI=1,23-1,76). ${ }^{35}$ Delima, dkk. juga menyatakan bahwa penyakit batu ginjal dapat mening- 
katkan risiko terjadinya penyakit ginjal kronik $(\mathrm{p}=0,006 ; \mathrm{OR}=3,03 ; 95 \% \mathrm{CI}=1,38-6,66) .{ }^{19}$ Obstruksi yang diakibatkan oleh batu saluran kemih dapat menyebabkan peningkatan tekanan intratubular yang diikuti oleh vasokonstriksi pembuluh darah hingga mengakibatkan iskemik pada ginjal. Iskemik pada waktu yang lama dapat menyebabkan glomeruloskerosis, atrofi tubulus dan fibrosis intertisial. Obstruksi komplit pada ginjal selama 24 jam akan mengakibatkan kehilangan fungsi nefron secara permanen sebanyak $15 \% .{ }^{22}$

Uji statistik menunjukkan bahwa tidak terdapat hubungan yang bermakna antara status obesitas dengan kejadian PGK pada penderita hi- pertensi. Penelitian ini sejalan dengan hasil penelitian Restianika yang membuktikan bahwa tidak terdapat hubungan antara riwayat obesitas dengan kejadian PGK. ${ }^{36}$ Kaze, FF., et al. juga membuktikan bahwa tidak terdapat hubungan yang bermakna anatara obesitas dengan kejadian penyakit ginjal kronik $(\mathrm{p}=0,196) \cdot{ }^{37}$ Namun, penelitian ini bertolak belakang dengan hasil penelitian Sulistiowati \& Sri yang membuktikan bahwa obesitas mempunyai risiko 2,5 kali lebih besar untuk mengalami risiko penyakit ginjal kronik. ${ }^{24}$ Begitu pula dengan penelitian Gonzalez, et al. yang membuktikan bahwa terdapat hubungan antara obesitas dengan penurunan nilai eGFR pada penderita hipertensi di Spanyol. ${ }^{11}$ Obesitas merupakan faktor yang ikut berperan dalam terjadinya penurunan LFG karena merupakan faktor predisposisi nefropati diabetik, nefrosklerosis hipertensi dan fokal atau segmental glomerulosklerosis serta pembentukan kalsium oksalat dan batu saluran kencing. Obesitas menyebabkan terjadinya lesi fokal segmental glomerulosklerosis (FSGS), penipisan membran basalis, gromerulomegali, podosit hipertropi, peningkatan matriks, dan gangguan fungsi ginjal. . $4,38,39,40$

Uji statistik membuktikan bahwa tidak ada hubungan yang bermakna antara kadar kolesterol total dengan kejadian penyakit ginjal kronik pada penderita hipertensi. Penelitian ini bertolak belakang dengan penelitian Sulistiowati \& Sri yang membuktikan adanya hubungan yang bermakna antara kadar kolesterol total dengan kejadian penyakit ginjal kronik $(p=0,01) \cdot{ }^{24}$ Hasil penelitian Senge membuktikan bahwa terdapat korelasi negatif bermakna $(r=-0,279, p=0,039)$, artinya semakin tinggi kadar kolesterol total, maka semakin rendah nilai eLFG. Penyakit ginjal dapat meningkatkan kadar lipid dan keadaan abnormalitas lipid berhubungan dengan risiko kardiovaskular. Pada pasien dengan PGK dan peningkatan kadar kolesterol total, dapat terjadi secara sekunder karena kehilangan protein dan urin. Peningkatan kadar kolesterol total dan abnormalitas lipid berperan pada kerusakan glomerulus. ${ }^{25}$

Uji statistik menunjukkan bahwa tidak ada hubungan yang bermakna antara kadar HDL dengan kejadian penyakit ginjal kronik pada penderita hipertensi. Penelitian ini sejalan dengan hasil penelitian Ayu, dkk. yang menyatakan bahwa tidak terdapat hubungan yang bermakna antara kadar HDL dengan kejadian PGK (OR=1,35; 95\% $\mathrm{CI}=0,61-2,99 ; \mathrm{p}=0,46) .{ }^{41}$ Sulistiowati \& Sri juga membuktikan tidak terdapat hubungan yang bermakna antara kadar HDL dengan kejadian penyakit ginjal kronik $(p=0,91) .{ }^{24}$ Namun, Senge, dkk. membuktikan bahwa terdapat hubungan antara HDL dengan eLFG dengan nilai $r$ sebesar $-0,024$ dan nilai $\mathrm{p}=0,863(>0,05) .{ }^{25}$ Penurunan HDL merupakan faktor progresivitas dari penyakit ginjal kronik. Hasil studi kohort menyatakan bahwa tingkat HDL-C yang rendah berkaitan dengan penurunan GFR dengan $\mathrm{p}$ value sebesar $0,017 .{ }^{42}$ Pada penelitian Helsinki Heart didapatkan subyek dengan rasio kolesterol-LDL/kolesterol-HDL $>4,4$ terjadi penurunan fungsi ginjal $20 \%$ lebih tinggi dibanding pada subyek dengan rasio $3,2 .{ }^{43}$

Uji statistik menunjukkan bahwa tidak ada hubungan yang bermakna antara kadar LDL dengan kejadian PGK pada penderita hipertensi. Penelitian ini sejalan dengan penelitian Sulistiowati \& Sri yang membuktikan tidak terdapat hubungan yang bermakna antara kadar LDL dengan kejadian penyakit ginjal kronik $(p=0,10) .{ }^{24}$ Namun, hasil penelitian Senge, dkk. membuktikan adanya hubungan antara kadar LDL dengan eLFG pada pasien penyakit ginjal kronik $(p=0,034)$. Artinya semakin tinggi kadar LDL, semakin rendah nilai eLFG. Studi Lubis, dkk. dalam Senge, dkk. juga melaporkan secara statistik bahwa ada hubungan yang bermakna antara LDL dengan PGK $(\mathrm{p}=0,002)$. Makin banyak kadar kolesterol LDL dalam plasma makin banyak yang akan mengalami oksidasi dan ditangkap oleh sel makrofag. Meningkatnya jumlah LDL kecil padat (small dense LDL) seperti pada sindrom metabolik dan diabetes melitus mempe- 
ngaruhi keadaan oksidasi termasuk pada PGK. ${ }^{25}$

Uji statistik menunjukkan bahwa tidak ada hubungan yang bermakna antara kadar trigliserida dengan kejadian penyakit ginjal kronik pada penderita hipertensi. Penelitian ini bertolak belakang dengan penelitian Sulistiowati \& Sri yang membuktikan adanya hubungan yang bermakna antara kadar trigliserida dengan kejadian penyakit ginjal kronik $(p=0,01) \cdot{ }^{24}$ Senge, dkk. juga membuktikan bahwa terdapat hubungan antara trigliserida dengan eLFG dengan nilai $r$ sebesar 0,293 dan nilai $p=0,030(<0,05)$. Artinya semakin tinggi kadar Tg, semakin tinggi pula nilai eLFG. Kadar kolesterol dan Tg yang tinggi berperan menimbulkan aterosklerosis. Buruknya sirkulasi ke sebagian besar organ menyebabkan aterosklerosis, hipoksia dan cedera jaringan, serta merangsang reaksi peradangan pada dinding pembuluh darah. Jika terjadi aterosklerosis suplai darah ke ginjal akan berkurang dan dapat menimbulkan gangguan pada LFG dan penurunan fungsi ginjal. ${ }^{25}$

\section{KESIMPULAN DAN SARAN}

Prevalensi kejadian PGK pada penderita hipertensi di Indonesia sebesar 0,5\%. Terdapat hubungan yang bermakna antara usia kategori 4554 tahun, usia kategori 55-64 tahun, jenis kelamin, riwayat $\mathrm{DM}$, dan riwayat batu ginjal dengan kejadian PGK pada penderita hipertensi di Indonesia. Riwayat DM, riwayat batu ginjal dan kadar kolesterol total merupakan variabel dominan kejadian PGK pada penderita hipertensi di Indonesia. Variabel lain yang berkontribusi besar terhadap kejadian PGK perlu dimuat pada riset yang akan dating, yaitu pola konsumsi air putih, konsumsi alkohol, konsumsi minuman bersoda, konsumsi minuman berenergi, dan penggunaan obat analgetika NSAID. Diperlukan kerjasama internal maupun lintas sektoral bagi kementerian kesehatan untuk mensukseskan upaya pencegahan dan pengendalian PGK pada faktor risiko dominan. Layanan kesehatan perlu melakukan pemantauan rutin terhadap faktor-faktor risiko, baik yang telah terbukti maupun yang berpotensi menjadi faktor risiko PGK pada penderita hipertensi. Perlu dilakukan penelitian dengan menambah variabel lainnya yang juga diduga ada hubungan dengan kejadian PGK pada penderita hipertensi, seperti status pengobatan hipertensi, lama menderita hipertensi, perilaku merokok, pola konsumsi air putih, konsumsi alkohol, konsumsi minuman bersoda, konsumsi minuman berenergi, dan penggunaan obat analgetika NSAID.

\section{UCAPAN TERIMA KASIH}

Ucapan terima kasih kami sampaikan kepada Kepala Badan Penelitian dan Pengembangan Kesehatan Kemenkes RI dan semua pihak yang telah membantu terselenggaranya penelitian ini.

\section{DAFTAR PUSTAKA}

1. Mardiana R. Analisis Praktikklinik Keperawatan Masalah Perkotaan pada Pasien Penyakit Ginjal Kronik di Ruang Melati Atas Rumah Sakit Umum Pusat Persahabatan Jakarta. Karya Ilmiah Ners: 2013.

2. Gabriellyn Sura Pongsibidang. Risiko Hipertensi, Diabetes, dan Konsumsi Minuman Herbal pada Kejadian Gagal Ginjal Kronik di RSUP Dr. Wahidin Sudirohusodo Makassar Tahun 2015. Jurnal Wiyata. 2016;162-167.

3. PENEFRI. 7th Report Of Indonesian Renal Registry. 2014.Available from: URL: http:// www.indonesianrenalregistry.org. Accessed January 19, 2017.

4. Titiek Hidayati, Haripurnomo Kushadiwijaya, Suhardi. Hubungan antara Hipertensi, Merokok dan Minuman Suplemen Energi dan Kejadian Penyakit Ginjal Kronik. Berita Kedokteran Masyarakat. 2008;24(2):90-102.

5. Susanto CE. Biaya Berobat Ginjal Triliunan. 2016. Available from: URL: http://www.mediaindonesia.com/news/read/33493/biaya-berobat-ginjal-triliunan/2016-03-11. Accessed February 17, 2017.

6. Fresenius Medical Care. ESRD Patients in 2012: A Global Perspective. 2012. Available from: URL: www.vision-fmc.com/files/pdf 2/ esrd patients 2012.pdf. Accessed January 19, 2017.

7. Fresenius Medical Care. ESRD Patients in 2013: A Global Perspective. 2013. Available from: URL: www.vision-fmc.com/files/pdf 2/ esrd patients 2013.pdf. Accessed January 19, 2017

8. PENEFRI. 5th Report Of Indonesian Renal Registry. 2012. Available from: URL: http:// www.indonesianrenalregistry.org. Accessed 
January 19, 2017.

9. Kementerian Kesehatan RI. Hasil Riset Kesehatan Dasar Tahun 2013. Badan Penelitian dan Pengembangan Kesehatan. 2013

10. Ghonemy TA, Farag SE, Soliman SA, El-okely A, El-hendy Y. Epidemiology and Risk Factors of Chronic Kidney Diseases in the E1 Sherkia Egypt. Saudi Journal of Kidney Diseases and Transplantation. 2016;27(1):111117.

11. Salvador-gonzález B, Mestre-ferrer J, Soler-vila M, Pascual-benito L, Alonso-bes Eva, Puertolas-cunillera $\mathrm{O}$, on behalf of the research group of the MARREC-HTA project.. Chronic kidney disease in hypertensive subjects $\geq 60$ years treated in Primary Care. 2017:1-9.

12. Phillips R, Acheampong JW, Saggar-malik AK, Cappuccio FP. Hypertension and renal failure in Kumasi, Ghana. 1999; (April 1995):37-40.

13. Laville M. Epidemiological Profile of Hypertensive Disease and Renal Risk Factors in Black Africa. PubMed Journals J Hypertens. 1994;7:839-843.

14. Kazancioglu R. Risk factors for chronic kidney disease: an update. 2013:368-371. doi:10.1038/kisup.2013.79.

15. Restu Pranandari, Woro Supadmi. Faktor Risiko Gagal Ginjal Kronik di Unit Hemodialisis Rsud Wates Kulon Progo. Majalah Farmaseutik. 2015;11(2):316-320.

16. Sri Hartini. Gambaran Karakteristik Pasien Gagal Ginjal Kronis yang Menjalani Hemodialisa di Rumah Sakit Umum Daerah Dr. Moewardi. 2016.

17. Australian Institute of Health and Welfare. An overview of chronic kidney disease in Australia. 2009.

18. Putri Gesti Floresa. Beberapa Faktor Risiko Penyakit Ginjal Kronik di RSD dr. SOEBANDI. Digital Repository Universitas Jember. 2015.

19. Delima dan Tim PGK. Studi Kasus Kontrol Gagal Ginjal Kronik (Faktor Risiko Penyakit Ginjal Kronik- Studi Kasus Kontrol ). 2014.

20. M, Muhammad Syafiqi Aries. Risk Factors Related to Incidence Of Chronic Kidney Disease in The Outpatient of dr Moewardi Hospital. Scientific Publication. Universitas Mu- hammadiyah Surakarta. 2016.

21. I, Laily dan Cholik Harun Rosjidi. Prevalensi Faktor Risiko Gagal Ginjal Kronik di RSUP Dr. Mohammad Hoesin Palembang Tahun 2012. MKS. 2014.

22. RM Suryadi Tjekyan. Prevalensi dan Faktor Risiko Penyakit Ginjal Kronik di RSUP Dr. Mohammad Hoesin Palembang Tahun 2012. 2014;(4):275-282.

23. Hengkesa P, Ivy Violan Lawalata. Faktor Risiko Penyakit Gagal Ginjal Kronik. Molucca Medica. 2015;72-81.

24. Eva Sulistiowati, Sri Idaiani. Faktor Risiko Penyakit Ginjal Kronik Berdasarkan Analisis Cross-sectional Data Awal Studi Kohort Penyakit Tidak Menular Penduduk Usia 25-65 Tahun di Kelurahan Kebon Kalapa, Kota Bogor Tahun 2011. Buletin Penelitian Kesehatan. 2015;1:14-17.

25. Senge CE, Moeis ES, Sugeng CEC. Hubungan Kadar Lipid Serum dengan Nilai Estimasi Laju Filtrasi Glomerulus pada Penyakit Ginjal Kronik. Jurnal e-Clinic (eCI). 2017;(5).

26. Manoy Y, Rampengan SH, Palar S. Hubungan Beberapa Faktor Risiko Penyakit Jantung Koroner dengan Laju Filtrasi Glomerulus pada Pasien Infark Miokard Lama. Universitas Sam Ratulangi. 2013.

27. Osafo C, Osafo C, Mate-kole M, Affram K, Adu D. Prevalence of Chronic Kidney Disease in Hypertensive Patients in Ghana. Article in Renal Failure. Informa Healthcare USA. 2016;(May 2011). doi:10.3109/088602 2X.2011.565140.

28. Kang YU, Kim HY, Choi JS, et al. Metabolic Syndrome and Chronic Kidney Disease in an Adult Korean Population: Results from the Korean National Health Screening. 2014;9(5). doi:10.1371/journal.pone.0093795.

29. Prakash S, O;Hare AM. Interaction of Aging and CKD. Semin Nephrol. 2009:497-503.

30. Hsieh M, DA Power. Abnormal Renal Function and Elecrolyte Disturbance in Older People. J Pharm Pract Res. 2009:230-234.

31. Scottish Intercollegiate. Diagnosis and Management of Chronic Kidney Disease. A National Guideline. Scottish Intercollegiate Guidelines Network. 2008:3-6.

32. Probosari. Faktor Risiko Gagal Ginjal pada 
Diabetes Mellitus. J Nutr Heal. 2013;1.

33. L Febriana. Hipertensi, Obesitas Sentral dan Diabetes Mellitus (Komponen Sindrom Metabolik) sebagai Prediktor Kejadian Penyakit Ginjal Kronik: Studi Kohort Retrospektif pada Penduduk Kecamatan Blahbatuuh Gianyar Bali. Thesis. Universitas Udayana. 2012.

34. Singh A, et al. Epidemiology and Risk Factors of Chronic Kidney Disease in India-Result from the SEEK (Screening and Early Evaluation of Kidney Disease. BMC Nephrol. 2013:114.

35. Shang W et al. History of Kidney Stones and Risk of Chronic Kidney Disease: A Meta-Analysis. PeerJ. 2017.

36. Restianika N. Faktor Yang Berhubungan dengan Kejadian Gagal Ginjal Kronik pada Pasien Rawat Inap Ruang Penyakit Dalam di RSUD Dr. Soeroto Kabupaten Ngawi. Universitas Jember. 2014.

37. Kaze FF, Kengne A, Magatsing CT, Halle M. Prevalence and Determinants of Chronic Kidney Disease Among Hypertensive Cameroonians According to Three Common Esti- mators of the Glomerular Filtration Rate Baseline Characteristics of the Study Population. 2016;18(5). doi:10.1111/jch.12781.

38. Eknoyan G. Obesity and Chronic Kidney Disease. Nefrologia. 2011:397-403.

39. Naumnik B, Mysliwiec M. Renal Consequences of Obesity. Med Sci Monit. 2010.

40. Kopple JD. Obesity and Chronic Kidney Disease. J Ren Nut. 2010:29-30.

41. Ayu P, Kandarini Y, Widiana GR, Sudhana W, Loekman JS, Suwitra K. Prevalensi dan Hubungan Sindrom Metabolik dengan Penyakit Ginjal Kronik pada Populasi Desa Legian, Kuta Bali. Jurnal Penyakit Dalam. 2011.

42. Baragetti A. High Density Lipoprotein Cholesterol Levels Are an Independent Predictor of The Progression of Chronic Kidney Disease. J Intern Med. 2013:252-262.

43. Bhagaskara. Hubungan Kadar Lipid dengan Kadar Ureum \& Kreatinin Pasien Penyakit Ginjal Kronik di RSUP Dr. Mohammad Hoesin Palembang Periode 1 Januari-31 Desember 2013. J Kedokt dan Kesehat. 2015;2:223-230. 